\title{
Large methyl halide emissions from south Texas salt marshes
}

\author{
R. C. Rhew ${ }^{1}$, M. E. Whelan ${ }^{1, *}$, and D.-H. Min ${ }^{2}$ \\ ${ }^{1}$ University of California at Berkeley, Department of Geography, Berkeley, CA 94720, USA \\ ${ }^{2}$ The University of Texas at Austin, Marine Science Institute, Port Aransas, TX 78373, USA \\ * now at: University of California, Merced, Sierra Nevada Research Institute, Merced, CA 95343, USA \\ Correspondence to: R. C. Rhew (rrhew@berkeley.edu)
}

Received: 24 April 2014 - Published in Biogeosciences Discuss.: 17 June 2014

Revised: 9 October 2014 - Accepted: 13 October 2014 - Published: 27 November 2014

\begin{abstract}
Coastal salt marshes are natural sources of methyl chloride $\left(\mathrm{CH}_{3} \mathrm{Cl}\right)$ and methyl bromide $\left(\mathrm{CH}_{3} \mathrm{Br}\right)$ to the atmosphere, but measured emission rates vary widely by geography. Here we report large methyl halide fluxes from subtropical salt marshes of south Texas. Sites with the halophytic plant, Batis maritima, emitted methyl halides at rates that are orders of magnitude greater than sites containing other vascular plants or macroalgae. B. maritima emissions were generally highest at midday; however, diurnal variability was more pronounced for $\mathrm{CH}_{3} \mathrm{Br}$ than $\mathrm{CH}_{3} \mathrm{Cl}$, and surprisingly high nighttime $\mathrm{CH}_{3} \mathrm{Cl}$ fluxes were observed in July. Seasonal and intra-site variability were large, even taking into account biomass differences. Overall, these subtropical salt marsh sites show much higher emission rates than temperate salt marshes at similar times of the year, supporting the contention that low-latitude salt marshes are significant sources of $\mathrm{CH}_{3} \mathrm{Cl}$ and $\mathrm{CH}_{3} \mathrm{Br}$.
\end{abstract}

\section{Introduction}

As atmospheric burdens of anthropogenic halocarbons decrease because of the Montreal Protocol, the relative importance of methyl halides for stratospheric ozone destruction increases. Methyl chloride $\left(\mathrm{CH}_{3} \mathrm{Cl}\right)$ and methyl bromide $\left(\mathrm{CH}_{3} \mathrm{Br}\right)$ are now the most abundant long-lived organochlorine and organobromine compounds, respectively (Montzka and Reimann, 2011). The atmospheric budgets of $\mathrm{CH}_{3} \mathrm{Cl}$ and $\mathrm{CH}_{3} \mathrm{Br}$ have large uncertainties arising from the fact that they have a multitude of major anthropogenic (e.g., biomass burning, fumigation use of $\mathrm{CH}_{3} \mathrm{Br}$, chemical feedstock use of $\mathrm{CH}_{3} \mathrm{Cl}$ ) and natural sources (e.g., oceans, terrestrial ecosystems), some of which are poorly characterized.
In our current understanding of the $\mathrm{CH}_{3} \mathrm{Br}$ budget, sinks outweigh the sources by about $30-35 \mathrm{Gg} \mathrm{yr}^{-1}$, or roughly 20-25\% of the total annual flux (Montzka and Reimann, 2011). This large "missing source" for $\mathrm{CH}_{3} \mathrm{Br}$ is present in both pre-phaseout (1996-1998) and current (2008) budgets and appears to be both natural and terrestrial in origin (YvonLewis et al., 2009). The $\mathrm{CH}_{3} \mathrm{Cl}$ budget may be balanced with a very large low-latitude terrestrial source (Xiao et al., 2010), and a few in situ studies of subtropical (Yokouchi et al., 2002, 2007) and tropical forests (Blei et al., 2010a; Saito et al., 2008) tentatively support this.

Coastal salt marshes have also been identified as globally significant sources of $\mathrm{CH}_{3} \mathrm{Cl}$ and $\mathrm{CH}_{3} \mathrm{Br}$, with emissions associated with halophytic vascular plants. However, measured emissions show dramatic geographic variability, with large emissions from southern California (Manley et al., 2006; Rhew et al., 2000, 2002) and much smaller emissions from higher-latitude sites in Tasmania, Australia (Cox et al., 2004), Scotland (Blei et al., 2010b; Drewer et al., 2006) and northern California (Rhew and Mazéas, 2010). Measurements from lower-latitude salt marshes have not yet been reported. In this study, we characterize the magnitude and seasonality of $\mathrm{CH}_{3} \mathrm{Cl}$ and $\mathrm{CH}_{3} \mathrm{Br}$ emissions from subtropical salt marshes in south Texas. Obtaining a wider latitudinal range of measurements from coastal salt marshes is essential to constrain their role in the global budget of methyl halides.

\section{Site description}

Five field outings were conducted between April 2006 and November 2009 at several salt marsh and coastal habitats on barrier islands in south Texas, USA, off the Gulf of Mexico (Table 1). Sites were all located between $27-28^{\circ} \mathrm{N}$ and 
$97-98^{\circ} \mathrm{W}$. All sites had sandy soils with elevations estimated at less than a meter above mean sea level. A total of 62 flux measurements were made at 24 individual sites from three different tidally influenced ecosystems.

The first field outing (TX1: 28 April 2006) took place on the southwestern shore of San Jose Island $\left(27^{\circ} 52^{\prime} \mathrm{N}\right.$, $97^{\circ} 03^{\prime} \mathrm{W}$ ), a sandy barrier island north of the city of Port Aransas. The goal of this initial outing was to survey emissions from predominant salt marsh plant species of the region: Borrichia frutescens (sea ox-eye daisy), Avicennia germinans (black mangrove), Monanthochloe littoralis (shore grass) and Batis maritima (maritime saltwort).

The second field outing (TX2: 16-18 May 2008) occurred at three different locations: San Jose Island (see TX1, two B. maritima sites, both slightly inundated during sampling), Mustang Island beach $\left(27^{\circ} 46^{\prime} \mathrm{N}, 97^{\circ} 6^{\prime} \mathrm{W}\right.$, six beached seaweed sites), and the Mollie Beattie Habitat Community on the back bay of Mustang Island $\left(27^{\circ} 38^{\prime} \mathrm{N}, 97^{\circ} 12^{\prime} \mathrm{W}\right.$, one $B$. maritima site). The goal of this second outing was to determine the daytime range of fluxes from the three $B$. maritima sites; to measure emissions from pelagic seaweed (Sargassum spp.) deposited on the Gulf-side beach at different stages of decomposition; and to determine the simultaneous gross consumption and production rates of methyl halides at all of these sites using a stable isotope tracer technique.

The third, fourth and fifth outings (TX3, TX4 and TX5) were all at the Mollie Beattie habitat (see TX2 above), on the fringe of a small saltwater pond, which was tidally connected with saline groundwater (Sect. S1 in the Supplement). The purpose of these outings was to capture the full diurnal (24h) range of fluxes from a pair of B. maritima sites located within $20 \mathrm{~m}$ of each other. These diurnal studies were conducted at three different times of the year: the early growing season (TX3: 7-8 March 2009), the peak growing season (TX4: 19-20 July 2009), and the end of the growing season (TX5: 6-7 November 2009). TX5 occurred after a period of heavy rain, and many of the $B$. maritima leaves were shed on the ground. Also, between 1 and 11 a.m. during TX5, both sites were tidally inundated, with the shorter vegetation site mostly underwater during the 7.30 and $10.30 \mathrm{a} . \mathrm{m}$. samplings.

Four vegetation-free control experiments were conducted: two beach sites after the removal of Sargassum (TX2), one salt marsh site with bare soil (TX4) and one salt marsh site inundated with $30 \mathrm{~cm}$ of tidal water (TX5).

\section{Methods}

Gas fluxes were measured with static flux chambers consisting of two components: a collar $\left(61 \mathrm{~L}, 0.264 \mathrm{~m}^{2}\right.$ footprint $)$ placed in the wet sand $>2 \mathrm{~cm}$ depth and an insulated chamber lid $(127 \mathrm{~L})$ with a $1 / 4$ in. stainless steel sample line used to withdraw air samples and two internal fans to mix the chamber air. All-aluminum chambers were used to limit reactivity with methyl halides, and dark chambers have been shown to yield similar methyl halide fluxes as light chambers in other salt marshes (Rhew and Mazéas, 2010). To initiate the enclosure period, the lid was placed into the waterfilled channel on the rim of the base. Enclosure times were $30 \mathrm{~min}$ or less $(30,22-28,20,16$ and $16 \mathrm{~min}$ for TX1-5, respectively), and three air samples were withdrawn from the chamber at equal time intervals. Samples were collected into previously evacuated $1 \mathrm{~L}$ electropolished stainless steel canisters (LabCommerce, San Jose, CA, USA) or $3 \mathrm{~L}$ fused silica lined canisters (Restek, Bellefonte, PA, USA). While sampling, a vent line was opened to equilibrate air pressure between inside and outside the chamber. In addition, ambient air samples were collected several times throughout each field campaign.

Air temperature (inside chamber and ambient air) and soil temperature (5 and $10 \mathrm{~cm}$ depth) were monitored with thermocouples (Omega Engineering Inc., Stamford, CT) during the first three outings and with stainless steel thermocouple data loggers (iButtons, Maxim Inc., Sunnyvale, CA, USA) for the last two outings. Soil moisture at $0-5 \mathrm{~cm}$ depth (ThetaProbe soil moisture sensor, Delta-T Devices, Cambridge, UK) and air pressure were monitored for each chamber experiment. For TX2-5, aboveground plant biomass was harvested, rinsed and drained before fresh weight was determined. Plants were then dried overnight at $65^{\circ} \mathrm{C}$ to determine the dry weight. Meteorological data including PAR, air pressure and air temperature were also measured at the Mission-Aransas National Estuarine Research Reserve monitoring station at the East Copano Bay, TX, USA (http: //lighthouse.tamucc.edu/MissionAransas/HomePage).

Air samples were measured for halocarbons $\left(\mathrm{CH}_{3} \mathrm{Br}\right.$, $\mathrm{CH}_{3} \mathrm{Cl}$ and $\mathrm{CHCl}_{3}$ ) by gas chromatography-mass spectrometry (GC/MS, Agilent 6890N/5973). Details regarding the inlet system, chromatography, gas standards and calibration procedures are described elsewhere (Rhew, 2011). Concentration trends were calculated using a linear regression of the chamber air concentration versus time, with goodness of fit assessed both by $R^{2}$ and the standard error on the slope. For the B. maritima sites, for example, $R^{2}$ values averaged 0.997 for $\mathrm{CH}_{3} \mathrm{Cl}$ and 0.995 for $\mathrm{CH}_{3} \mathrm{Br}$. Net fluxes were calculated by multiplying this slope with the moles of air in the chamber, divided by the enclosed surface area; net flux errors were calculated by propagating the errors of each of these components. For consistency, all fluxes are reported in units of $\mu \mathrm{mol} \mathrm{m}{ }^{-2} \mathrm{~d}^{-1}$ unless otherwise indicated, with negative values representing consumption rates and positive values representing production rates. Also, a stable isotope tracer technique was applied in the TX2 outing to separate the net flux into the gross production and gross consumption components (Sect. S2). All times are reported as US central standard time $(\mathrm{CST}=\mathrm{GMT}-6 \mathrm{~h})$. 


\section{Results}

\subsection{TX1: April 2006}

Of the various vegetation sites sampled during TX1, the largest emissions by far were from the $B$. maritima site (triangles in Fig. 1), which emitted $580 \pm 30 \mu \mathrm{mol} \mathrm{m}{ }^{-2} \mathrm{~d}^{-1} \mathrm{CH}_{3} \mathrm{Cl}$ and $30 \pm 12 \mu \mathrm{molm}^{-2} \mathrm{~d}^{-1} \mathrm{CH}_{3} \mathrm{Br}$. As a comparison, the largest reported emissions observed from a salt marsh previously were 570 and $42 \mu \mathrm{mol} \mathrm{m}{ }^{-2} \mathrm{~d}^{-1}$, respectively (Rhew et al., 2002; Manley et al., 2006). The A. germinans site showed emissions $<0.5 \%$ of the $B$. maritima site, while the two $B$. frutescens sites and the $M$. littoralis site showed small to insignificant net emissions of $\mathrm{CH}_{3} \mathrm{Cl}\left(<0.3 \mu \mathrm{molm}^{-2} \mathrm{~d}^{-1}\right)$ and $\mathrm{CH}_{3} \mathrm{Br}\left(<0.012 \mu \mathrm{mol} \mathrm{m}{ }^{-2} \mathrm{~d}^{-1}\right)$.

\subsection{TX2: May 2008}

In TX2, the three $B$. maritima sites showed large net emissions of methyl halides, comparable to TX1. Emission rates increased throughout the day (8.50 a.m. to 2.20 p.m.), although the sampling period was too short to fully assess diurnal trends. One site had a maximum flux of $620 \pm$ $20 \mu \mathrm{mol} \mathrm{m}^{-2} \mathrm{~d}^{-1} \mathrm{CH}_{3} \mathrm{Cl}$ and $39 \pm 2 \mu \mathrm{mol} \mathrm{m}^{-2} \mathrm{~d}^{-1} \mathrm{CH}_{3} \mathrm{Br}$, which at that point represented the largest $\mathrm{CH}_{3} \mathrm{Cl}$ and second largest $\mathrm{CH}_{3} \mathrm{Br}$ emission rate per unit area from a natural source yet observed.

The three freshly deposited Sargassum sites at the Gulf coast beach showed net emissions that were 3 orders of magnitude smaller that the B. maritima sites (Fig. 1 and Table 1). Three other sites of Sargassum that were visibly at a more advanced stage of decomposition and desiccation showed similar net emissions. When two of the Sargassum sites were cleared of seaweed and measured as control experiments on a bare sand surface, net emissions were an order of magnitude smaller still. Gross consumption rates measured with stable isotope tracers were negligibly small (Sect. S2).

\subsection{TX3, TX4 and TX5: March, July and November 2009}

The next three outings each captured the diurnal variability of $\mathrm{CH}_{3} \mathrm{Cl}$ and $\mathrm{CH}_{3} \mathrm{Br}$ fluxes over a $24 \mathrm{~h}$ period from a pair of B. maritima-dominated sites (Fig. 2). The day/night differences in emissions were much more pronounced for $\mathrm{CH}_{3} \mathrm{Br}$ than for $\mathrm{CH}_{3} \mathrm{Cl}$. For $\mathrm{CH}_{3} \mathrm{Br}$, the maximum daytime averages were 2.3 times greater than the nighttime averages $(n=6$ sites), whereas the difference for $\mathrm{CH}_{3} \mathrm{Cl}$ was 1.3 times. The molar ratio of $\mathrm{CH}_{3} \mathrm{Cl}$ to $\mathrm{CH}_{3} \mathrm{Br}$ fluxes also showed a day to night difference (Fig. 2), shifting from roughly $40: 1$ at night to $20: 1$ during the daytime.

Surprisingly, the maximum observed $\mathrm{CH}_{3} \mathrm{Cl}$ emission flux in July $\left(630 \pm 10 \mu \mathrm{mol} \mathrm{m}^{-2} \mathrm{~d}^{-1}\right)$ occurred in the middle of the night ( 1 a.m.). In fact, this represented the highest observed emission rate from all the outings, comparable to the highest flux from TX2. The lowest emissions were observed during

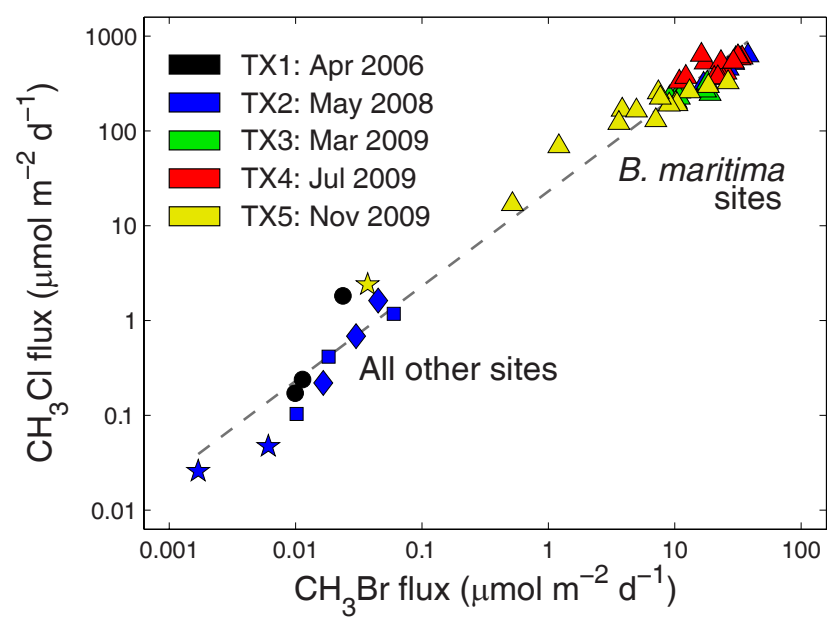

Figure 1. Net fluxes of $\mathrm{CH}_{3} \mathrm{Cl}$ and $\mathrm{CH}_{3} \mathrm{Br}$ for all field sites in south Texas. Triangles: B. maritima; squares: fresh Sargassum; diamonds: decaying Sargassum; circles: other vegetation (M. littoralis, A. germinans, B. frutescens), stars: vegetation-free control. Note the $\log -\log$ scale. The gray dashed line shows the overall average $23: 1$ molar ratio. Two chambers that had small negative fluxes are not included.

November (TX5) during the morning at one site when the vegetation was almost entirely submerged by high tide. The other site also was submerged at the time, but had slightly more vegetation above the surface of the water.

To derive an integrated daily flux, the fluxes at each site were modeled by a cosine function during daylight hours, with steady emissions assumed at night (Fig. 2, Sect. S3). Of these three outings, the largest average diel emissions were in July (TX4) at $455 \pm 130 \mu \mathrm{molm}^{-2} \mathrm{~d}^{-1}$ for $\mathrm{CH}_{3} \mathrm{Cl}$ and $22 \pm 5 \mu \mathrm{mol} \mathrm{m}^{-2} \mathrm{~d}^{-1}$ for $\mathrm{CH}_{3} \mathrm{Br}$. March emissions were roughly half of those, and November emissions were slightly lower than March (Table 1, Fig. 3). Even though nighttime measurements were not used in the model, the difference between the modeled to measured nighttime values was only $-4 \pm 11 \%$ (or $-20 \pm 50 \mu \mathrm{mol} \mathrm{m}^{-2} \mathrm{~d}^{-1}$ ) for $\mathrm{CH}_{3} \mathrm{Cl}$ and $5 \pm 22 \%$ (or $1 \pm 2 \mu \mathrm{mol} \mathrm{m}^{-2} \mathrm{~d}^{-1}$ ) for $\mathrm{CH}_{3} \mathrm{Br}$. Thus the model was applied to the May (TX2) sites as well (Table 1).

\section{Discussion}

The predominance of $B$. maritima emissions over emissions from other measured plant and macroalgal species is similar to observations from southern California salt marshes, where $B$. maritima was one of the two largest emitters of methyl halides (Manley et al., 2006; Rhew et al., 2002). However, B. maritima sites from Texas generally showed much larger diel averaged emissions of $\mathrm{CH}_{3} \mathrm{Cl}$ and $\mathrm{CH}_{3} \mathrm{Br}$ than those from southern California, especially outside the peak summer growing season (Fig. 3). Even normalized by biomass, emission rates from Texas sites were roughly 10 
Table 1. Field conditions and predominant vegetation at Texas coastal field sites.

\begin{tabular}{|c|c|c|c|c|c|c|c|}
\hline \multirow{2}{*}{$\begin{array}{l}\text { Outing/date: }(\mathrm{dd} / \mathrm{mm} / \mathrm{yy}) \\
\text { Enclosed species }\end{array}$} & \multirow{2}{*}{$\begin{array}{l}\text { Location } \\
n\end{array}$} & \multicolumn{2}{|c|}{ Net flux $\left(\mu \mathrm{molm}{ }^{-2} \mathrm{~d}^{-1}\right)$} & \multicolumn{2}{|c|}{ Modeled diel flux ${ }^{\mathrm{a}}$} & \multirow{2}{*}{\multicolumn{2}{|c|}{$\frac{\text { Batis biomass }}{\mathrm{kg} \mathrm{m}^{-2}}$}} \\
\hline & & $\mathrm{CH}_{3} \mathrm{Cl}$ & $\mathrm{CH}_{3} \mathrm{Br}$ & $\mathrm{CH}_{3} \mathrm{Cl}$ & $\mathrm{CH}_{3} \mathrm{Br}$ & & \\
\hline \multicolumn{6}{|c|}{ TX1: 28/04/06 San Jose Island } & fresh & dry \\
\hline Batis maritima & 1 & $584 \pm 27$ & $30 \pm 12$ & - & - & N/D & N/D \\
\hline Avicennia germinans & 1 & $1.8 \pm 0.4$ & $0.023 \pm 0.010$ & - & - & -- & \\
\hline Various $^{b}$ & 3 & $\leq 0.2$ & $\leq 0.02$ & - & - & -- & \\
\hline \multicolumn{8}{|c|}{ TX2: 16/05/08-18/05/08 San Jose Island, Mustang Island Beach and Mollie Beattie } \\
\hline B. maritima $(\text { site } \mathrm{A})^{\mathrm{c}}$ & 3 & $409 \pm 115$ & $23 \pm 5$ & 296 & 16 & 1.44 & 0.25 \\
\hline B. maritima $(\text { site } \mathrm{B})^{\mathrm{c}}$ & 3 & $371 \pm 80$ & $22 \pm 4$ & 230 & 15 & 1.38 & 0.23 \\
\hline Sargassum (fresh) & 3 & $0.56 \pm 0.55$ & $0.029 \pm 0.027$ & - & - & - & - \\
\hline Sargassum (decaying) & 3 & $0.84 \pm 0.72$ & $0.030 \pm 0.014$ & - & - & - & - \\
\hline Sand (beach) & 2 & $0.04 \pm 0.02$ & $0.004 \pm 0.003$ & - & - & - & - \\
\hline B. maritima (site C) & 3 & $494 \pm 115$ & $29 \pm 8$ & 287 & 16 & 1.58 & 0.30 \\
\hline \multicolumn{8}{|c|}{ TX3: 07/03/09-08/03/09 Mollie Beattie } \\
\hline B. maritima (site A) & 5 & $220 \pm 30$ & $13 \pm 5$ & 222 & 13 & 1.52 & $0.28^{\mathrm{d}}$ \\
\hline B. maritima (site B) & 5 & $270 \pm 40$ & $13 \pm 4$ & 266 & 13 & 1.34 & $0.24^{\mathrm{d}}$ \\
\hline \multicolumn{8}{|c|}{ TX4: 20/07/09-21/07/09 Mollie Beattie } \\
\hline B. maritima (site A) & 7 & $571 \pm 43$ & $27 \pm 7$ & 547 & 25 & 1.66 & 0.31 \\
\hline B. maritima (site B) & 7 & $374 \pm 28$ & $20 \pm 6$ & 362 & 18 & 1.68 & 0.29 \\
\hline Sand (marsh) & 1 & $-0.073 \pm 0.061$ & $0.004 \pm 0.002$ & - & - & - & - \\
\hline \multicolumn{8}{|c|}{ TX5: 06/11/09-07/11/09 Mollie Beattie } \\
\hline B. maritima $(\text { site } \mathrm{A})^{\mathrm{c}}$ & 7 & $165 \pm 30$ & $7.0 \pm 2.9$ & 156 & 6 & 0.66 & 0.13 \\
\hline B. maritima $(\text { site } \mathrm{B})^{\mathrm{c}}$ & 7 & $207 \pm 117$ & $10.7 \pm 9.4$ & 265 & 11 & 0.75 & 0.13 \\
\hline Saltwater (marsh) ${ }^{\mathrm{c}}$ & 1 & $2.40 \pm 0.07$ & $0.037 \pm 0.001$ & - & - & - & - \\
\hline
\end{tabular}

${ }^{\text {a }}$ modeled diel flux $\left(\mu \mathrm{mol} \mathrm{m}^{-2} \mathrm{~d}^{-1}\right)$ based on daytime measurements;

${ }^{\mathrm{b}}$ Borrichia frutescens and Monanthochloe littoralis;

${ }^{c}$ soil surface covered with water for some or all measurements;

d vegetation $\mathrm{H}_{2} \mathrm{O}$ estimated as $81.9 \%$ based on average of other outings.

times larger than Newport Bay California sites (monthly averages) (Manley et al., 2006).

The production of $\mathrm{CH}_{3} \mathrm{Cl}$ and $\mathrm{CH}_{3} \mathrm{Br}$ at $\mathrm{B}$. maritima sites are related, as illustrated by a strong linear correlation $\left(R^{2}=0.78\right)$. These fluxes also showed moderate correlations with chamber air temperature, surface soil temperature and biomass $\left(R^{2}=0.40\right.$ to 0.53 , Figs. S1 and S2 in the Supplement). Within individual outings, however, these environmental factors were poor predictors. For example, large flux differences were observed between two adjacent sites with similar biomass (e.g., TX4 and TX5) and could even show a slightly negative relationship (e.g., TX3). $\mathrm{CH}_{3} \mathrm{Cl}$ and $\mathrm{CH}_{3} \mathrm{Br}$ showed no correlation with net fluxes of chloroform and carbonyl sulfide (Whelan et al., 2013) that were measured simultaneously (Figs. S1 and S2).

The very large nighttime emissions in July when temperatures were also high suggest that temperature is a more proximate control on emission rates than insolation. This is consistent with studies in southern California (Rhew et al., 2002) and Scotland (Blei et al., 2010b), but contrasts with earlier studies in Scotland (Drewer et al., 2006) and Ireland (Dimmer et al., 2001). At another salt marsh site in southern California, Manley et al. (2006) found that B. maritima emissions were less correlated with either temperature or insolation compared to other plants. We suggest that, for studies that use transparent chambers, the effect of insolation and temperature may be difficult to separate without monitoring leaf temperatures directly or actively modulating the temperature in the chamber. This does not discount the importance of insolation, which regulates seasonal changes in temperature and biomass.

The average $\mathrm{CH}_{3} \mathrm{Cl}: \mathrm{CH}_{3} \mathrm{Br}$ molar flux ratio of $22 \pm 9$ is slightly greater than southern and northern California salt marsh averages (7-17) (Manley et al., 2006; Rhew et al., 2002; Rhew and Mazéas, 2010) and is much higher than the ratios of 2-4 reported from higher-latitude salt marshes (Blei et al., 2010b; Cox et al., 2004; Dimmer et al., 2001). This is consistent with the observation of Blei et al. (2010b) 

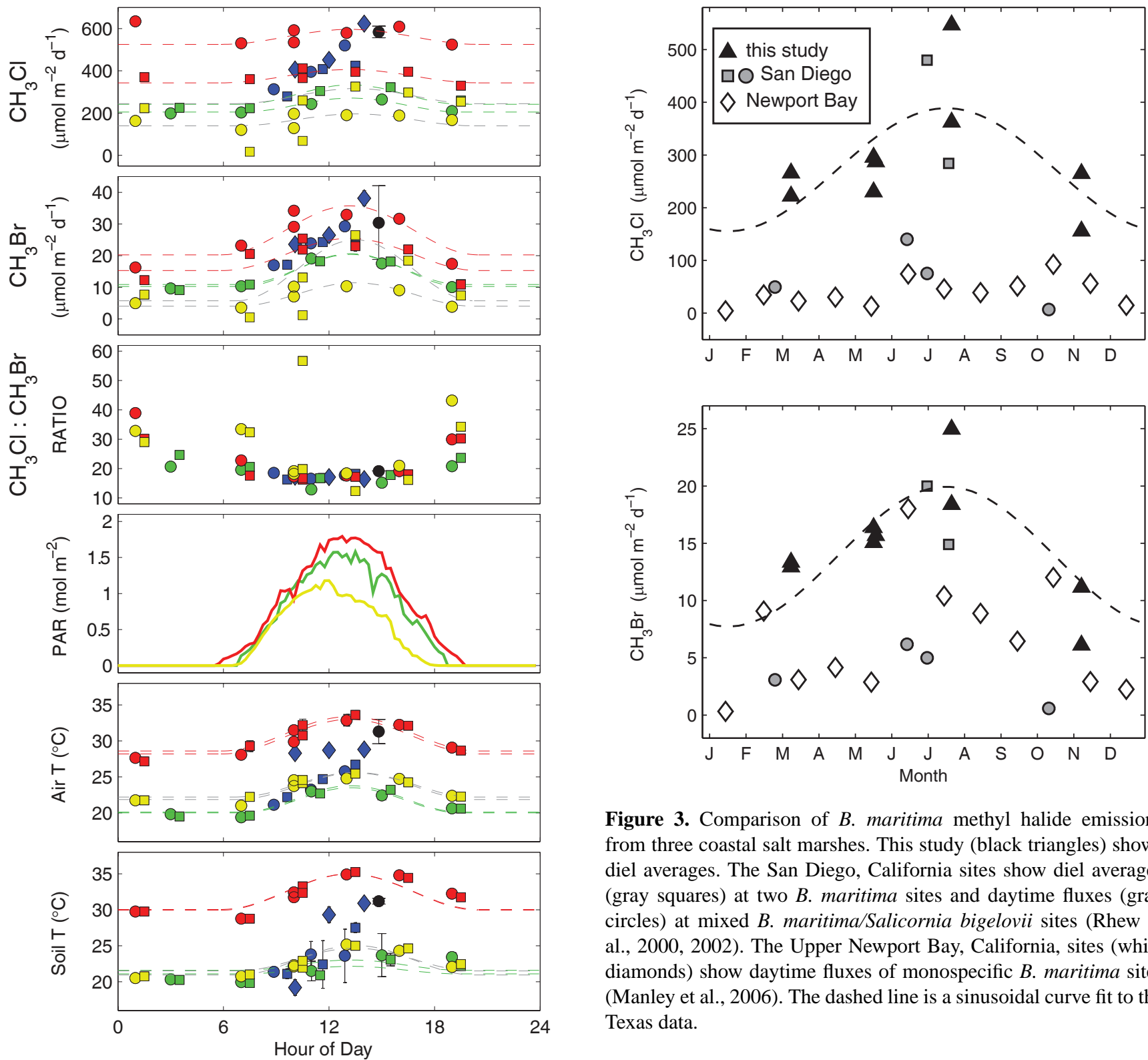

Fure 3. Comparison of B. maritima methyl halide emissions from three coastal salt marshes. This study (black triangles) shows diel averages. The San Diego, California sites show diel averages (gray squares) at two B. maritima sites and daytime fluxes (gray circles) at mixed B. maritima/Salicornia bigelovii sites (Rhew et al., 2000, 2002). The Upper Newport Bay, California, sites (white diamonds) show daytime fluxes of monospecific $B$. maritima sites (Manley et al., 2006). The dashed line is a sinusoidal curve fit to the Texas data.

Figure 2. Net fluxes of $\mathrm{CH}_{3} \mathrm{Cl}$, net fluxes of $\mathrm{CH}_{3} \mathrm{Br}$, the $\mathrm{CH}_{3} \mathrm{Cl}$ to $\mathrm{CH}_{3} \mathrm{Br}$ flux ratio, photosynthetically active radiation (PAR), chamber air temperature and surface soil temperature at $B$. maritima sites versus time of day (central standard time). Colors represent different outings, as in Fig. 1; different symbols (circles, squares, diamonds) represent different sites at the same outing. Error bars that are smaller than the symbols are not shown. The dashed lines represents the model fit to TX3-5 (March, July, and November) results. PAR is a $15 \mathrm{~min}$ interval measurement averaged over the 2 days of each field outing.

that the salt marshes from more temperate climates generally have lower emission ratios. However, this is not a consequence of higher temperatures leading to higher ratios. At the Texas B. maritima sites, molar ratios did not dramatically

shift with the seasons, and the molar ratios of emissions were higher at night $(\sim 40)$ and lower during the day $(\sim 20)$, opposite of the temperature trends (Fig. 2).

This diurnal trend in ratios is clearly related to the much larger diurnal variation in $\mathrm{CH}_{3} \mathrm{Br}$ flux compared to $\mathrm{CH}_{3} \mathrm{Cl}$ flux, as illustrated by the pronounced midday $\mathrm{CH}_{3} \mathrm{Br}$ peak in this study (Fig. 2). Interestingly, this same trend in molar ratios was also observed in a San Diego salt marsh (Rhew et al., 2002), where it mirrored a diurnal shift in the carbon isotopic ratio $\left(\delta^{13} \mathrm{C}\right)$ of $\mathrm{CH}_{3} \mathrm{Cl}$ and $\mathrm{CH}_{3} \mathrm{Br}$. In that study, carbon isotopic signatures were heavier at night $\left(-50 \%{ }_{0} \mathrm{CH}_{3} \mathrm{Cl}\right.$ and $-10 \%$ o $\left.\mathrm{CH}_{3} \mathrm{Br}\right)$ compared to daytime $\left(-70 \%\right.$ o $\mathrm{CH}_{3} \mathrm{Cl}$ and $-60 \% \mathrm{CH}_{3} \mathrm{Br}$ ), with the isotopic shift much more pronounced for $\mathrm{CH}_{3} \mathrm{Br}$ than $\mathrm{CH}_{3} \mathrm{Cl}$ (Bill et al., 2002). 
Two hypotheses were proposed to explain these diurnal trends of ratios and isotopic signatures (Bill et al., 2002; Rhew et al., 2002): (1) biogenic production dominates during the day, while soil consumption becomes more significant at night; and (2) two different production mechanisms with different isotopic signatures and ratios of production occur simultaneously.

The first hypothesis could explain the lower overall net emission rates and heavier isotopic signatures at night (since consumption favors lighter isotopes; Miller et al., 2001), but this study and others (Rhew and Mazéas, 2010) suggest that gross consumption is trivial in salt marshes compared to B. maritima production rates, even at night (Sect. S2). Also, gross consumption generally favors $\mathrm{CH}_{3} \mathrm{Cl}$ uptake over $\mathrm{CH}_{3} \mathrm{Br}$ by a molar factor of 30-40 (Rhew, 2011; Rhew and Mazéas, 2010), such that if nighttime consumption is important, the net emission ratio of $\mathrm{CH}_{3} \mathrm{Cl}$ to $\mathrm{CH}_{3} \mathrm{Br}$ should decrease at night, not increase.

The second hypothesis is supported by having two known production mechanisms of methyl halides from B. maritima: the enzymatically mediated methylation of halides ( $\mathrm{Ni}$ and Hager, 1999; Wuosmaa and Hager, 1990) and an abiotic reaction between plant pectin and halides (Hamilton et al., 2003; Wishkerman et al., 2008). Because the abiotic mechanism yields a very light isotopic signature $\left(\delta^{13} \mathrm{C}\right.$ of $-78 \%$ for B. maritima) (Keppler et al., 2004), a large abiotic increase during the daytime relative to enzymatic production could explain the isotopic shift. However, the $\mathrm{CH}_{3} \mathrm{Cl}: \mathrm{CH}_{3} \mathrm{Br}$ molar ratio of production for the abiotic mechanism is also larger (45-58) (Wishkerman et al., 2008) than the predicted enzymatic production (20-1) (Rhew et al., 2002), which would yield a larger diurnal shift for $\mathrm{CH}_{3} \mathrm{Cl}$ than $\mathrm{CH}_{3} \mathrm{Br}$, which is not observed.

An alternative hypothesis involves both a diurnal shift in the isotope signature of the carbon substrate used to produce methyl halides combined with a shift in methylation ratios of the halides. If production is predominantly biological, a diurnal shift in the $\delta^{13} \mathrm{C}$ signature of the methyl donor $(S$ adenosyl-L-methionine) (Ni and Hager, 1999) and/or higher isotopic fractionation rates during the daytime could yield the observed isotopic signal. It is also possible that the abiotic production mechanism produces lighter $\delta^{13} \mathrm{C}$ methyl halides at higher temperatures, but the carbon source for abiotic production comes from structural components of a plant that are not necessarily expected to have diurnal variation in $\delta^{13} \mathrm{C}$ (Keppler et al., 2004).

The other half of this hypothesis involves the $\mathrm{Cl} / \mathrm{Br}$ ratios in the plant changing during the day. Bromide is preferentially halogenated by both biotic and abiotic mechanisms relative to their availability ( $\mathrm{Ni}$ and Hager, 1998; Wishkerman et al., 2008) and may be replenished during the day and depleted at night, perhaps in conjunction with transpiration rates. However, the amount of chloride and bromide that is volatilized daily via methyl halide emission is not large enough to substantially change the overall $\mathrm{Cl}^{-}$and $\mathrm{Br}^{-}$con- tent in plant tissue. In this study, the biomass normalized diel emission rates of $\mathrm{CH}_{3} \mathrm{Cl}$ and $\mathrm{CH}_{3} \mathrm{Br}$ were $1.25 \pm 0.40$ and $0.062 \pm 0.014 \mu \mathrm{mol} \mathrm{gdwt}{ }^{-1} \mathrm{~d}^{-1}$, respectively ( $n=9$ sites). If we assume that the $B$. maritima tissue halide contents are similar to those measured in southern California B. maritima plants $\left(210 \mathrm{mg} \mathrm{g}^{-1}\right.$ for $\mathrm{Cl}^{-}$and $2900 \mu \mathrm{g} \mathrm{g}^{-1}$ for $\mathrm{Br}^{-}$; Manley et al., 2006), then we estimate that roughly $0.02 \%$ of $\mathrm{Cl}$ and $0.17 \% \mathrm{Br}$ in the leaf tissue is removed daily via methyl halide emissions. Thus, to impact halide availability, there would need to be a small segregated subset of "active" halides at the enzyme site. If this "active" halide pool was $0.5 \%$ of the overall tissue content, then the methyl halide emissions could reduce that pool by $4 \%$ for $\mathrm{Cl}$ and $34 \%$ for $\mathrm{Br}$ daily. This would lead to an increased $\mathrm{CH}_{3} \mathrm{Cl}$ to $\mathrm{CH}_{3} \mathrm{Br}$ emission ratio, until the halide levels were replenished. A subset of "active" halides in the cytoplasm of plant cells is implied by $\mathrm{Ni}$ and Hager $(1998,1999)$, who proposed that the function of halide methyltransferase is to dispose of excess chloride to regulate internal concentrations.

The Texas salt marsh fluxes measured over several months strongly suggest a seasonality of fluxes. Assuming that the seasonality can be characterized with a sinusoidal fit to the diel averaged data (Fig. 3) and that these measurements are temporally and spatially representative, we derive an estimated annual flux of $92 \mathrm{mmolm}^{-2} \mathrm{yr}^{-1}$ for $\mathrm{CH}_{3} \mathrm{Cl}$ and $4.7 \mathrm{mmol} \mathrm{m}^{-2} \mathrm{yr}^{-1}$ for $\mathrm{CH}_{3} \mathrm{Br}$. These annual values are 2 to 3 times larger than those estimated for the B. maritima sites in Upper Newport Bay $\left(28 \mathrm{mmol} \mathrm{m}^{-2} \mathrm{yr}^{-1}\right.$ for $\mathrm{CH}_{3} \mathrm{Cl}$ and $2.4 \mathrm{mmol} \mathrm{m}^{-2} \mathrm{yr}^{-1}$ for $\mathrm{CH}_{3} \mathrm{Br}$ ) (Manley et al., 2006). Sampling over the full range of environmental conditions would help refine these estimates of the annual flux.

The surface area coverage of $B$. maritima in Texas salt marshes was not quantified for this study. In Newport Bay, California, B. maritima covered $10 \%$ of the entire salt marsh area (including barren areas) and $18 \%$ of the vegetated area (Manley et al., 2006). For the purpose of comparison, we will assume that these Texas salt marshes have the same B. maritima coverage and that the remaining 82-90\% of salt marshes have negligible emission rates. Spatially averaged emissions for the entire salt marsh are then estimated at 9-17 and 0.47-0.84 $\mathrm{mmol} \mathrm{m}^{-2} \mathrm{yr}^{-1}$ for $\mathrm{CH}_{3} \mathrm{Cl}$ and $\mathrm{CH}_{3} \mathrm{Br}$, respectively. These fluxes are slightly greater than those reported from Newport Bay salt marshes (3-8 and 0.2-0.7 $\mathrm{mmol} \mathrm{m}^{-2} \mathrm{yr}^{-1}$ for $\mathrm{CH}_{3} \mathrm{Cl}$ and $\mathrm{CH}_{3} \mathrm{Br}$, respectively, with the range representing total area and only vegetated areas), which have other large emissions associated with Frankenia grandifolia (Manley et al., 2006). However, these rates are 1 to 2 orders of magnitude greater than annually averaged salt marsh fluxes in Scotland $\left(0.11 \mathrm{mmol} \mathrm{m}^{-2} \mathrm{yr}^{-1}\right.$ for $\mathrm{CH}_{3} \mathrm{Cl}$ and $0.03 \mathrm{mmolm}^{-2} \mathrm{yr}^{-1}$ for $\mathrm{CH}_{3} \mathrm{Br}$ ) (Blei et al., 2010b; Drewer et al., 2006). The Scotland salt marsh fluxes are similar in magnitude to other high-latitude salt marshes, including Tasmania, Australia (Cox et al., 2004) and northern California (Rhew and Mazéas, 2010). 
Collectively, these studies show that methyl halide emissions from coastal salt marshes have a strong climatic dependence, with small emissions at higher latitudes and large emissions at lower latitudes. This climatic dependence may be related to both temperature (higher temperatures yield faster enzymatic and abiotic production rates of methyl halides) and insolation (greater photosynthesis rates lead to greater biomass, with associated increases in relevant secondary metabolites and enzymes). B. maritima alone may be responsible for globally significant amounts of methyl halides, as it is an evergreen succulent shrub found widely in tropical and subtropical salt marshes, brackish marshes and mangrove swamps ranging from northern Brazil $\left(3^{\circ} \mathrm{S}\right)$ to South Carolina $\left(33^{\circ} \mathrm{N}\right.$ ) (Lonard et al., 2011). A major uncertainty involves the spatial distribution and global coverage of coastal wetlands, with 2.2-40 Mha of tidal marsh and 13.8-15.2 Mha of mangroves (Pendleton et al., 2012). As an illustrative exercise, if $B$. maritima or similarly emitting plants cover $10 \%$ of the surface area of tidal marshes and mangroves, and if averaged emissions are as calculated here, then this subset of salt marsh vegetation would contribute 30-90 Gg $\mathrm{CH}_{3} \mathrm{Cl}$ and 3-9 Gg $\mathrm{CH}_{3} \mathrm{Br}$ per year. Deriving a more accurate global source strength will require a much broader geographic distribution of measurements, along with better estimates of ecosystem surface areas and plant distributions. Clarifying the importance of coastal salt marsh vegetation in the global budgets of $\mathrm{CH}_{3} \mathrm{Cl}$ and $\mathrm{CH}_{3} \mathrm{Br}$ will require further measurements at low-latitude salt marsh sites.

\section{Conclusions}

Large emissions of $\mathrm{CH}_{3} \mathrm{Cl}$ and $\mathrm{CH}_{3} \mathrm{Br}$ were observed from subtropical salt marshes located on the Gulf coast of Texas. These large emissions were associated with $B$. maritima, a widespread succulent salt marsh plant that was also observed to be a large emitter in southern California salt marshes. However, B. maritima emission rates in this study were 2 to 3 times larger than those reported from California, and spatially averaged emission rates from Texas salt marshes were much larger overall than those reported from higher-latitude salt marsh sites. Diurnal trends in $\mathrm{CH}_{3} \mathrm{Cl}$ and $\mathrm{CH}_{3} \mathrm{Br}$ emission rates, along with their ratio of emissions, were similar to those observed in southern California salt marshes. To derive a better estimate of the global salt marsh contribution to the atmospheric budgets of the methyl halides, more information is needed about the spatial extent, vegetation cover and methyl halide emission rates from low-latitude salt marsh sites.

\section{The Supplement related to this article is available online} at doi:10.5194/bg-11-6427-2014-supplement.
Acknowledgements. The authors thank F. Ernst, K. Dunton, I.-N. Kim and T. W. Kim (UTMSI) and Y.-T. Chen (UCB) for field support; S. Manley (CSU-LB) for data comparisons; the Bass Company and A. Nuñez (Texas General Land Office) for field site access and coordination. Research was supported by UCB, UT Austin, and the Schweppe Endowment at UTMSI. This is the University of Texas Marine Science Institute Contribution No. 1681 .

Edited by: X. Wang

\section{References}

Bill, M., Rhew, R. C., Weiss, R. F., and Goldstein, A. H.: Carbon isotope ratios of methyl bromide and methyl chloride emitted from a coastal salt marsh, Geophys. Res. Lett., 29, 1045, doi:10.1029/2001GL012946, 2002.

Blei, E., Hardacre, C. J., Mills, G. P., Heal, K. V., and Heal, M. R.: Identification and quantification of methyl halide sources in a lowland tropical rainforest, Atmos. Environ., 44, 1005-1010, doi:10.1016/j.atmosenv.2009.12.023, 2010a.

Blei, E., Heal, M. R., and Heal, K. V.: Long-term $\mathrm{CH}_{3} \mathrm{Br}$ and $\mathrm{CH}_{3} \mathrm{Cl}$ flux measurements in temperate salt marshes, Biogeosciences, 7 , 3657-3668, doi:10.5194/bg-7-3657-2010, 2010b.

Cox, M. L., Fraser, P. J., Sturrock, G. A., Siems, S. T., and Porter, L. W.: Terrestrial sources and sinks of halomethanes near Cape Grim, Tasmania, Atmos. Environ., 38, 3839-3852, 2004.

Dimmer, C. H., Simmonds, P. G., Nickless, G., and Bassford, M. R.: Biogenic fluxes of halomethanes from Irish peatland ecosystems, Atmos. Environ., 35, 321-330, 2001.

Drewer, J., Heal, M. R., Heal, K. V., and Smith, K. A.: Temporal and spatial variation in methyl bromide flux from a salt marsh, Geophys. Res. Lett., 33, L16808, doi:10.1029/2006g1026814, 2006.

Hamilton, J. T. G., McRoberts, W. C., Keppler, F., Kalin, R. M., and Harper, D. B.: Chloride methylation by plant pectin: an efficient environmentally significant process, Science, 301, 206-209, 2003.

Keppler, F., Kalin, R. M., Harper, D. B., McRoberts, W. C., and Hamilton, J. T. G.: Carbon isotope anomaly in the major plant C-1 pool and its global biogeochemical implications, Biogeosciences, 1, 123-131, doi:10.5194/bg-1-123-2004, 2004.

Lonard, R. I., Judd, F. W., and Stalter, R.: The biological flora of coastal dunes and wetlands: Batis maritima C. Linnaeus, J. Coast. Res., 27, 441-449, doi:10.2112/jcoastres-d-10-00142.1, 2011.

Manley, S. L., Wang, N.-Y., Walser, M. L., and Cicerone, R. J.: Coastal salt marshes as global methyl halide sources from determinations of intrinsic production by marsh plants, Global Biogeochem. Cy., 20, GB3015, doi:10.1029/2005gb002578, 2006.

Miller, L. G., Kalin, R. M., McCauley, S. E., Hamilton, J. T. G., Harper, D. B., Millet, D. B., Oremland, R. S., and Goldstein, A. H.: Large carbon isotope fractionation associated with oxidation of methyl halides by methylotrophic bacteria, P. Natl. Acad. Sci. USA, 98, 5833-5837, 2001.

Montzka, S. A. and Reimann, S.: Chapter 1: Ozone-Depleting Substances (ODSs) and Related Chemicals, in: Scientific Assessment of Ozone Depletion: 2010, edited by: Ravishankara, A. R., 
Newman, P. A., Pyle, J. A., and Ajavon, A.-L. N., World Meteorological Organization, Geneva, Switzerland, 2011.

Ni, X. H. and Hager, L. P.: cDNA cloning of Batis maritima methyl chloride transferase and purification of the enzyme, P. Natl. Acad. Sci. USA, 95, 12866-12871, 1998.

Ni, X. H. and Hager, L. P.: Expression of Batis maritima methyl chloride transferase in Escherichia coli, P. Natl. Acad. Sci. USA, 96, 3611-3615, 1999.

Pendleton, L., Donato, D. C., Murray, B. C., Crooks, S., Jenkins, W. A., Sifleet, S., Craft, C., Fourqurean, J. W., Kauffman, J. B., Marba, N., Megonigal, P., Pidgeon, E., Herr, D., Gordon, D., and Baldera, A.: Estimating global "blue carbon" emissions from conversion and degradation of vegetated coastal ecosystems, PLoS ONE, 7, e43542, doi:10.1371/journal.pone.0043542, 2012.

Rhew, R. C.: Sources and sinks of methyl bromide and methyl chloride in the tallgrass prairie: Applying a stable isotope tracer technique over highly variable gross fluxes, J. Geophys. Res., 116, G03026, doi:10.1029/2011jg001704, 2011.

Rhew, R. C. and Mazéas, O.: Gross production exceeds gross consumption of methyl halides in northern California salt marshes, Geophys. Res. Lett., 37, L18813, doi:10.1029/2101GL044341, 2010.

Rhew, R. C., Miller, B. R., and Weiss, R. F.: Natural methyl bromide and methyl chloride emissions from coastal salt marshes, Nature, 403, 292-295, 2000.

Rhew, R. C., Miller, B. R., Bill, M., Goldstein, A. H., and Weiss, R. F.: Environmental and biological controls on methyl halide emissions from southern California coastal salt marshes, Biogeochemistry, 60, 141-161, 2002.

Saito, T., Yokouchi, Y., Kosugi, Y., Tani, M., Philip, E., and Okuda, T.: Methyl chloride and isoprene emissions from tropical rain forest in Southeast Asia, Geophys. Res. Lett., 35, L19812, doi:10.1029/2008GL035241, 2008.
Whelan, M. E., Min, D. H., and Rhew, R. C.: Salt marsh vegetation as a carbonyl sulfide (COS) source to the atmosphere, Atmos. Environ., 73, 131-137, doi:10.1016/j.atmosenv.2013.02.048, 2013.

Wishkerman, A., Gebhardt, S., McRoberts, C. W., Hamilton, J. T. G., Williams, J., and Keppler, F.: Abiotic methyl bromide formation from vegetation, and its strong dependence on temperature, Environ. Sci. Technol., 42, 6837-6842, doi:10.1021/es800411j, 2008.

Wuosmaa, A. M. and Hager, L. P.: Methyl chloride transferase: a carbocation route for biosynthesis of halometabolites, Science, 249, 160-162, 1990.

Xiao, X., Prinn, R., Fraser, P., Simmonds, P., Weiss, R., O’Doherty, S., Miller, B., Salameh, P., Harth, C., Krummel, P., Porter, L., Mühle, J., Greally, B. R., Cunnold, D., Wang, R., Montzka, S., Elkins, J., Dutton, G. S., Thompson, T. M., Butler, J., Hall, B., Reimann, S., Vollmer, M. K., Stordal, F., Lunder, C., Maione, M., Arduini, J., and Yokouchi, Y.: Optimal estimation of the surface fluxes of methyl chloride using a 3-D global chemical transport model, Atmos. Chem. Phys., 10, 5515-5533, doi:10.5194/acp10-5515-2010, 2010.

Yokouchi, Y., Ikeda, M., Inuzuka, Y., and Yukawa, T.: Strong emission of methyl chloride from tropical plants, Nature, 416, 163-165, 2002.

Yokouchi, Y., Saito, T., Ishigaki, C., and Aramoto, M.: Identification of methyl chloride-emitting plants and atmospheric measurements on a subtropical island, Chemosphere, 69, 549-553, doi:10.1016/j.chemosphere.2007.03.028, 2007.

Yvon-Lewis, S. A., Saltzman, E. S., and Montzka, S. A.: Recent trends in atmospheric methyl bromide: analysis of post-Montreal Protocol variability, Atmos. Chem. Phys., 9, 5963-5974, doi:10.5194/acp-9-5963-2009, 2009. 